\title{
LAUGHING IN THE FACE OF PATRIARCHY: GENESIS RABBAH 17
}

\author{
Tali Artman Partock*
}

\begin{abstract}
This paper argues that parashah 17 of Genesis Rabbah 17, which interprets the biblical story of the creation of woman from the rib, is a carefully edited text, which tackles not only the origins of humankind but also of misogyny. It shows that its structure develops from praise of women, to parodies on women haters and hatred, using what Bakhtin referred to as carnivalesque forms of humour. It also reflects on the reasons humour has not been pointed at by previous scholars.
\end{abstract}

\section{To Ran}

In the past two decades, after the Bible and even the Zohar started showing us their laughing faces, the realization that 'our rabbis, may their memory be blessed' might have had a rather creative sense of humour, has begun to spread.' Jokes, anecdotes, and even parodies of both the Hebrew Bible and the New Testament were identified. Suddenly the Babylonian rabbis could mock the Palestinian rabbis, Jews could mock Christians, the old Israelites the men of Sodom, and in moments of special divine grace some rabbis were even willing to enjoy a good laugh at the expense of their own learning and meaning-making mechanisms. ${ }^{2}$ But even those who saw the laughing face of the rabbis (mostly Babylonian rabbis) did not find it in their hearts to include misogyny or patriarchy as objects of mockery, or even self-reflection in rabbinic literature. ${ }^{3}$ But what if this is a mistake? Where would such a text appear? What would it look like? Would we be able to see it?

The attempt that I wish to make here is to take a text that has been interpreted as the rabbinic 'heart of darkness' when it comes to women,' the last part of parashah 17 of Genesis Rabbah, and suggest that it could be our own 'horizon of expectations' that blinds us from seeing the complex forms of cultural production that appear in it, and its comic, ironic, even satirical aspects.

To achieve this, I will first address the nature of the editing of Genesis Rabbah, then theoretical issues, and only then will I turn to a (very) close reading of Genesis Rabbah 17.

As Boyarin has already invested some 400 pages in showing the relevance of the serio-comic to talmudic culture, I have no need to repeat his argument. ${ }^{6}$ However, to read an ancient text as comic,

\footnotetext{
* University of Cambridge. Email: ta378@cam.ac.uk

I would like to thank the members of Seder Nashim at Shalom Hartman Institute and the Israel Institute for their support, as well as offer my gratitude to Natasha Gordinsky, Daniel Weiss, Galit Hasan-Rokem and Laliv Clenman.

'Ruth Kara-Ivanov Kaniel, "Seed That Comes From Another Place: The Metamorphosis of the Story of Lot's Daughters," Jerusalem Studies in Jewish Thought 22 (2011): 91-119.

${ }^{2}$ Arkadi Kovelman, "Farce in the Talmud," Review of Rabbinical Judaism 5:1 (2002): 86-92; Don Waisanen, Hershey Friedman, and Linda Friedman, "What's So Funny about Arguing with God? A Case for Playful Argumentation from Jewish Literature," Argumentation 29/1 (2015): 57-80; Chaim W. Reines, "Laughter in Biblical and Rabbinic Literature," Judaism 21 (1972): 176-83; Leonard J. Greenspoon, Jews and Humor (West Lafayette: Purdue University Press, 2011); Holger Michael Zellentin, Rabbinic Parodies of Jewish and Christian Literature (Tübingen: Mohr Siebeck, 2011); Jakob Jónsson, Humour and Irony in the New Testament: Illuminated by Parallels in Talmud and Midrash, with a Foreword by Krister Stendahl, and an Epilogue (Leiden: Brill, 1985); Dina Stein, "Let the "people" Go?" Prooftexts 29/2 (2009): 206-41; Rella Kushelevsky, "The Function of Humor in Three Versions of the Theme Rabbi Joshua Ben Levi and the Angel of Death,” Jerusalem Studies in Jewish Folklore 19-20 (1998): 329-44 [Hebrew]. Erich S. Gruen, Heritage and Hellenism: The Rejuvenation of Jewish Tradition (Berkeley; London: University of California Press, 1998); Daniel Boyarin, Socrates and the Fat Rabbis (Chicago: University of Chicago Press, 2009).

Atalia Brener, Are We Amused? Humour about Women in the Biblical Worlds (London; New York: T\&T Clark/Continuum, 2003); Conrad Hyers, And God Created Laughter: The Bible as Divine Comedy (Atlanta: Westminster John Knox Press, 1987); Melissa A. Jackson, Comedy and Feminist Interpretation of the Hebrew Bible: A Subversive Collaboration (Oxford: Oxford University Press, 2012). Levinson did it in order to show how a story in Leviticus Rabbah undermines both biblical and rabbinic norms, and even the patriarchal structure itself - but only when its subjects are all men: Joshua Levinson, "Upside Down World: The Story of the Drunk and His Sons," Jerusalem Studies in Hebrew Literature 14 (1993): 7-29 [Hebrew].

${ }^{4}$ Daniel Boyarin, Carnal Israel: Reading Sex in Talmudic Culture (Berkeley; Oxford: University of California Press, 1995), 88-90; Judith Baskin, Midrashic Women: Formations of the Feminine in Rabbinic Literature (Hanover; London: University of New England for Brandeis University Press, 2002), 66-9.

Mostly based on MS London (but while keeping an eye on other manuscripts), and on comparisons to other rabbinic and nonrabbinic texts.

Boyarin, Socrates.
} 
or even to be able to spot what is funny in it, is a very complicated and dangerous endeavour, as Goldhill and others have noticed. We sometimes lose the exact meaning of some ancient slang word, a cultural context, a bodily gesture. We are not sure when a joke is really made, or that we are not laughing in all the wrong places. ${ }^{7}$ On top of this, as Tal Ilan notices, the Palestinian sources are often regarded (perhaps unjustly) as humourless. ${ }^{8}$ How can we still make suggestions, then, that something is indeed funny, or that someone intended something to be strange, absurd, comic?

The answers may be found in the ancient texts themselves. Some humour does travel and translates well. This is the kind of humour that is based on exaggerations, word games, repetitions and other forms of attracting attention to the gap between 'the text' and 'the world'.

But in order to spot such textual features, we must assume that they were the work of someone; that an author (implied or real, anonymous or named, one or many) toiled to create them. In our case we must read a parashah in Genesis Rabbah as a unit, and assume that a very involved and creative editor takes the place of the 'author'.

Before I examine the nature of authorship and the comic in Genesis Rabbah, I would like to explain how this is a feminist study of Midrash. Reading this parashah of Genesis Rabbah as comic or rather serio-comic, risks running into one of the biggest aporiae in the field of feminist studies in rabbinic literature. Put very briefly, to argue that rabbinic literature and culture is androcentric and, at times, misogynistic/chauvinistic wins women scholars the crown of being outdated and trivial. ${ }^{9}$ To argue that this view is not monolithic and, by comparison, not so bad is deemed to be apologetic. ${ }^{10}$ To speak of 'the body' and 'identity" is to forget that the female body was the one subdued by the male body, and that questions of identity were a male privilege in antiquity. How, then, can one still write from a feminist perspective? I suggest laughing our way out of this dead end. Assuming that the editor of parashah 17 had a sense of humour does not make him a feminist, or a chauvinist. It does make him, regardless of his 'sins', the first to cast a stone out of the rabbinic glass house. Parashah 17 of Genesis Rabbah uses the comic, or rather the serio-comic for a moment of self-reflection, in which the discourse about women is offered for reappraisal.

\section{Editorial issues: the death of the author and the revival of the editor}

For most of the twentieth century, the consensus was that the editor of Genesis Rabbah was mainly a collector. The exegetical nature of Genesis Rabbah, following closely the biblical verses in sequence, and the fact that at times different drashot on the same verse appeared one after the other, supported this. Genesis Rabbah was envisioned a little bit like 'Torah Shlema'," an encyclopaedia for rabbinic interpretation of Genesis until the fifth century. However, scholars of midrash noticed quite early the importance of the anonymous editor of aggadic material. Heinemann set the tone for thinking of the editor of the slightly later hermeneutical Midrash, Leviticus Rabbah, as sophisticated and masterful, while

\footnotetext{
${ }^{7}$ Simon Goldhill, “Good, Dirty Fun,” Times Literary Supplement August 31, 2016; Mary Beard, Laughter in Ancient Rome: On Joking, Tickling, and Cracking Up (Berkeley: University of California Press, 2014).

${ }^{8}$ Tal Ilan, "The Joke in Rabbinic Literature: Home-born or Diaspora Humor?", in Georges Tamer, ed., Humor in Arabic Culture (Berlin: De Gruyter 2009), 57-75. Boyarin also seems to focus his discussions of humor mainly on the Babylonian Talmud in his Socrates and the Fat Rabbis.

${ }^{9}$ Ishay Rosen-Zvi's attempt to teach Baskin feminism is a good example: Ishay Rosen Zvi, "Misogyny and its Discontent," review of Judith Baskin, Midrashic Women: Formations of the Feminine in Rabbinic Literature, Prooftexts 20 (2005): 221.

${ }^{10}$ See Boyarin's discussion in Boyarin, Carnal Israel, 20.

"On this trend and of this trend, see Ishay Rosen-Zvi "The Rise and Fall of Rabbinic Masculinity," Jewish Studies, an Internet Journal [JSIJ 12 (2013): 1-22; Charlotte Fonrobert, "Regulating the Human Bodv: Rabbinic Legal Discourse and the Making of Jewish Gender," in Charlotte Fonrobert and Martin Jaffee, eds., The Cambridge Companion to the Talmud and Rabbinic Literature (Cambridge: Cambridge University Press, 2007), 270-73 and many others.

${ }^{12}$ Menachem Mendel Kasher, Humash Torah shelemah: ve-hu ha-Torah shebi-khetav 'im be'ur "Torah shebe-'al peh” (Jerusalem: Noam Aharon, 1994) [Hebrew].
} 
assuming that the editor(s) of Genesis Rabbah were not quite as involved and in control of their texts. ${ }^{13}$ However, in the late 1980s a different voice was heard: that of Genesis Rabbah scholar Ofra Meir. ${ }^{14}$ In her many readings of Genesis Rabbah she often noticed the skilful hand of an editor, and described some of his (or their) techniques. Slowly, a recognition that at least some of Genesis Rabbah's parashot were carefully edited and structured, and that its editors were far more than collectors, started to spread. In the early 1990s Philip Alexander remarked, while reading a whole parashah as a close unit: 'The fact that the text is built up from small, essentially self-contained units, does not mean that it can only be read atomistically. The units, wherever their origin, have been marshalled in a highly skilful way in order to create a sustainable discourse on a limited repertory of theological themes. ${ }^{15}$ The final nails in the coffin of the no/low editing theory at least for some of the parashot of Genesis Rabbah, were driven in by Melikovsky and Kahana. Melikovsky argued fiercely that the first and the last parashot in Genesis Rabbah are by no means open-ended or half-edited, and made the case against comparing its editing to that of the Yerushalmi. ${ }^{16}$ Kahana called the editor of parashat 'Bereshit Bara' no less than a masterpedagogue as he showed how the whole of the parashah is structured around the number six, and clearly sided with Meir. ${ }^{17}$

To link their works to my argument, I believe that the editor of Genesis Rabbah 17 may have collected his materials from multiple sources, and that each drasha in it may still stand alone. But the parashah, the work of the editor, holds a different meaning, crafted carefully to create a whole, which is bigger than the sum of its parts. The editor, in other words, is its author. In Socrates and the Fat Rabbis, Boyarin labours to show the structural parallels between Plato as the redactor of Socratic dialogues and the editors of the Babylonian Talmud Suggiyot. I wish to stress that some of his insights about the redactors of the Bavli hold true to other rabbinic texts, and in particular to this parashah in Genesis Rabbah. To mimic Boyarin's claims about the Bavli, we can argue that the parashah in Genesis Rabbah is also based on the existence of what Goldhill calls 'a clamping principle" ${ }^{18}$ - an anonymous voice that makes a text into a discourse. This 'transparent', anonymous being holds immense power, as it is his consciousness that shapes the text that we read. The text, as Barthes argues, '... is a tissue of quotations drawn from the innumerable centres of culture' and 'the writer can only imitate a gesture that is always anterior, never original. His only power is to mix writings, to counter the ones with others, in such a way as never to rest on any one of them. ${ }^{19}$ The editor is a dead author, in a Barthian sense. Nothing or almost nothing of what this author has to say is his own original thought. Nevertheless, the structure he builds is his unique work of art. Boyarin sees this as 'precisely the stance of the subject-position of the stamma' - the anonymous author of the Talmud. ${ }^{20}$ He defines this stamma as a token or a type animating all narrative discourse, a type of 'implied author'. ${ }^{21}$ I believe the editor of the midrashic parashah functions in the same way. Indeed, one of the criticisms brought against Boyarin's book was that the same type of

${ }^{13}$ Joseph Heinemann, "The Structure and Division of Genesis Rabba," in H. Z. Hirschberg et al., eds., Jubilee Volume for Hayyim Moshe Shapira (Ramat Gan: Bar-Ilan University Press, 1972), 279-89 [Hebrew]; Joseph Heinemann, "Profile of a Midrash: The Art of Composition in Leviticus Rabba," Journal of the American Academy of Religion 39 (1971): 141-50.

${ }^{14}$ Ofra Meir, "A Garden in Eden: On the Redaction of "Genesis Rabba,"” Dappim: Research in Literature 6/5 (1989): 309-30 [Hebrew]; Ofra Meir, "Ekron ha'haluka leparashot b’bereshit Rabba," Proceedings of the Tenth World Congress of Jewish Studies 3/1 (2000): 101-8; Meir, 'Ma'ase ha'arikha bebereshit rabba ub'vayikra rabba,' Teuda 11 (1996): 61-90.

${ }^{15}$ Philip Alexander, "Pre-Emptive Exegesis: Genesis Rabba's Reading of the Story of Creation," Journal of Jewish Studies $43 / 3$ (1992): 233-4.

${ }^{16}$ Chaim Milikowsky, "On the Formation and Transmission of Bereshit Rabba and the Yerushalmi: Questions of Redaction, TextCriticism and Literary Relationships,” The Jewish Quarterly Review 92/3-4 (2002): 521-67.

${ }^{17}$ Menachem Kahana, "Shes mishzar: Le'Sidura shel parashat 'Bereshit Bara' be'midrash Bereshit Rabbah,” in Joshua Levinson, Jacob Elbaum, Galit Hasn-Rokem, eds., Higayon L'Yona: New Aspects in the Study of Midrash, Aggadah and Piyyut In Honor of Professor Yona Fraenkel (Jerusalem: Magnes, 2007), 370-1.

${ }^{18}$ Simon Goldhill, "Becoming Greek, with Lucian," in Who Needs Greek? Contests in Cultural History of Hellenism (New York: Cambridge University Press, 2002), 60-107.

${ }^{19}$ Roland Barthes, "The Death of the Author," in William Irwine, ed., The Death and Resurrection of the Author. Contributions in Philosophy 83 (Westport, Conn.: Greenwood Press, 2002), 6. As quoted by Boyarin, Socrates, 203.

${ }^{20}$ Boyarin, Socrates, 203.

${ }^{21}$ Ibid., 204. 
implied authorship, which brings into dialogue elements that seemingly do not belong together, exists throughout rabbinic literature, not only in the Babylonian Talmud. ${ }^{22}$

\section{Laughter, a serious matter}

Now that we have established the editor of parashah 17 as an author, we must turn to his literary devices; those techniques that I argue enable us to discern what is serious, what is comic, and what is serio-comic. My theory of laughter here is always based on Bakhtin's concept of double-voiced speech. Doublevoiced speech is the term Bakhtin uses to define a discourse that holds two sometimes conflicting voices together. The fact that one utterance can say a thing and its opposite at the same time is the heart of parody ${ }^{23}$ as much as it is the heart of the serio-comic, and the satiric mode. ${ }^{24}$ The laughter that belongs to the realm of the carnival may be less refined, but is still part of this type of discourse. While the laughter in the carnival is a violent form of destruction (i.e. monological in nature) its goal is regeneration, not death. Put differently, in the very act of (verbal) destruction, a second, reviving and renewing voice is heard. The carnival itself, therefore, is a double-voiced speech, a parody.

But whose voices are these? The midrashic text displays two levels of what Bakhtin called passive double-voiced speech: $:^{26}$ one in the words of the 'smaller units' collected, and another in the expression through the act of editing of the midrashic editor/redactor of the parashah. At each point, both the utterance and the sequence may be double-voiced. It is our task to discern whose consciousness is leading the discussion: the unit's or the editor's. It may sound complicated, but thankfully Classics scholarship has already solved some of the problems, by separating Socratic and Platonic irony. Charles L. Griswold writes: 'Socratic [irony] is communicated within the context of the dialogue, a context which is (fictionally) oral rather than written,' a statement which easily transfers to midrash. He continues: 'On both the Socratic and Platonic levels of irony a doubling of meaning occurs .... Irony may be a way of speaking (or writing) which is meant to point to what is not spoken (or written)'. ${ }^{27}$ He goes on: 'In the context of the Platonic dialogues, irony does not necessarily come to meaning the opposite of what one is saying. Nor should we infer that irony is, at least in Plato, the expression of something that is false...What makes Socratic irony in particular so complicated is that the statements in question are in different ways both false and true. ${ }^{98}$ This special feature, the statement that may be regarded as both false and true, is key to my reading of Genesis Rabbah. ${ }^{29}$ But before we continue to the reading of the parashah, Platonic irony should be defined. Griswold defines it by those signs in the text that imply that, even if Plato is not represented in the dialogue as a character, he still functions in it. This could be done through the description of gestures, non-verbal acts of the characters, the title of the dialogue and so forth. The three strongest and most helpful markers, however, are Plato's putting of the same arguments into the mouths of different characters (repetition), his very choice of characters, and the presentation of the dialogue as being either narrated or performed. ${ }^{30}$ As we shall see, those last three markers of Platonic irony are scattered across Genesis Rabbah 17.

\footnotetext{
${ }^{22}$ Reuven Kiperwasser, review of Daniel Boyarin, Socrates and the Fat Rabbis, Jewish History 25/3/4 (2011): 382.

${ }^{23}$ Mikhail Bakhtin, Problems of Dostoevsky's Poetics, trans. Caryl Emerson (Minneapolis and London: University of Minnesota Press, 1984), 192-4.

${ }^{24}$ Boyarin, Socrates, 235-6.

${ }^{25}$ Mikhail Bakhtin, Rabelais and his World, trans. Helene Iswolsky (Bloomington: Indiana University Press, 1984 ), 11.

${ }^{26}$ Bakhtin, Problems, 192-4.

${ }^{27}$ Charles L. Griswold, "Irony in the Platonic Dialogues,” Philosophy and Literature 26 (2002): 88.

${ }^{28}$ Griswold, 'Irony,' 88-9.

${ }^{29}$ This can be taken as an equivalent to Boyarin's definition of the serio-comic: the ability to be serious and comic at the same time without pretending that there is harmony between the two.

${ }^{30}$ Griswold, "Irony", 96-8.
} 


\section{The past of an illusion:}

Parashah 17 of Bereshit Rabbah comments only on Genesis 2:18-21, from God's decision that it is not good for man to be alone, until God's taking of Adam's rib. ${ }^{32}$ It wanders, however, quite freely in the trails of the first three chapters of Genesis, and is as much about the creation of men as it is about the creation of women, as we shall soon see.

The second creation story in Genesis 2-3, which begins with God's observation that it is not good for man to be alone, has served many patriarchal and misogynist religious theories of women. Some of the most venomous appeared quite early (Philo, Questiones in Genesis 1:25-58; De Opificio Mundi 151-179; Sirach, 25:21-25). 1 Timothy 2:11-15 was not far from Jewish Hellenistic thought when it interpreted Genesis 2 like this: ${ }^{11}$ Let a woman (wife) learn in silence with full submission. ${ }^{12}$ I permit no woman (wife) to teach or to have authority over a man (her husband); she is to keep silent. ${ }^{18}$ For Adam was formed first, then Eve; ${ }^{14}$ and Adam was not deceived, but the woman was deceived and became a transgressor. ${ }^{15}$ Yet she will be saved through childbearing, provided they continue in faith and love and holiness, with modesty. ${ }^{33}$ This interpretation of Genesis still has some strongholds in both modern Jewish and Christian communities, and is perhaps an epitome of the twisted logic of misogyny. After all, if those who were created first should rule those created last, it is the insects and vermin that should have inherited the earth. And let us not forget that Adam might have still peacefully roamed Eden, had he not also been deceived.

As decades of feminist interpretations of Genesis have shown, there is nothing in the second chapter of Genesis to stop someone who wants to interpret it along different lines. ${ }^{34}$ While there is no doubt that the Bible reflects patriarchy and patriarchal values, it is still a rather serious leap to see it as misogynistic. The many, many interpreters that read it as a text that testifies to women's inferiority have imposed their own ideology onto the text. Some men of old, who heard and read these texts never failed to see in their self-serving interpretations a manifestation of divine inspiration, and some modern men, a manifestation of superior interpretative skills. ${ }^{35}$ But let us read without their ghosts, before we fall under their spell again.

\section{Setting the tone: was woman an afterthought? Are women good or evil?}

Genesis Rabbah 17, the parashah that deals with the creation of woman, opens with a straightforward attack on Paul and all those who believe that the second creation narrative, in which God made woman out of the rib of man, was a sign of the inferiority not only of the first woman, but of womankind:

We have learned in the Mishnah, by ten acts of speech was the world made [Mishnah Avot 5:1]. And those are: 'In the beginning God Created' (Gen. 1:1). 'And the spirit of God hovered' (Gen. 1:2). 'And God said, let there be light' (Gen. 1:3). 'And God said, let there be a firmament' (Gen. 1:6). 'And God said, let the water

\footnotetext{
${ }^{31}$ Thus making the principle of dividing into parashot in Genesis Rabba according to opened and closed ones in the Bible, or according to the Palestinian tri-annual cycle of reading the Torah irrelevant. See Kahana, "Shesh," $368-9$, and the literature mentioned there.

${ }^{32}$ It is interesting to note that despite the alleged 'encyclopedic nature' of the midrash and its offering of exegesis on all the verses of Genesis in sequence, verse 17 of Chapter 2, the one which warns Adam not to eat from the tree of knowledge is not commented upon at all. It is also worth mentioning that the parashah indeed begins by commenting on Genesis 1, hardly keeping in sequence. This parashah indeed has a theme, much like those of Leviticus Rabbah.

${ }^{3}$ All English translations of the New Testament in this article are in agreement with NRSV.

${ }^{34}$ The women and men who wrote about the second creation story from different feminist perspectives are too many to be able to mention them all - from Elizabeth Cady Stanton, Simon de Beauvoir, Kate Millet, Esther Fuchs, Mieke Bal (all mentioned and survived by Ilana Pardes, Countertraditions in the Bible (Cambridge and London: Harvard University Press, 1993), 13-38), to Phyllis Tribel, Carol Mayers, Susan Lanser, David Clines, Phyllis Bird, David Jobling and others referred to in Danna Nolan Fewell, "Reading the Bible Ideologically: Feminist Criticism,” in Steven L. McKenzie and Stephen R. Haynes, eds., To Each Its Own Meaning: An Introduction to Biblical Criticisms and Their Application (Louisville: Westminster John Knox Press, 1999), 268-82.

${ }^{3 i}$ Phyllis Trible, God and the Rhetoric of Sexuality (London: SCM, 1978).
} 
gather together' (Gen. 1:9). 'And God said, let the earth bring forth grass' (Gen. 1:11).' And God said, let there be lights' (Gen. 1:14). 'And God said, Let the water swarm' (Gen. 1:20). 'And God said, Let the earth bring forth' (Gen. 1:24).' And God said, Let us make man' (Gen. 1:26). Menahem ben Rabbi Yose removes the verse 'and the spirit of God hovered over the face of the water' (Gen. 1:12) and replaces it with 'and God said it is not good for man to be alone' (Gen. 2:18). Said Rabbi Jacob bar Qirshai, a separate speech act was assigned to the spirit by itself.

Opening the parashah on the creation of the two sexes with the inclusion of womankind in the original divine ten sayings by which God created the world, i.e., in His original plan, is highly significant. The creation of woman and womankind was not an afterthought, nor a desideratum of the creation of the human male. Women were created equal. Even the words of bar Qirshai do not negate this, as he may as well have included the creation of womankind in the saying 'let us make man'. ${ }^{36}$

The parashah continues with an identification of women with blessing, joy, life, help, atonement, and while it does acknowledge the fact that some women may be bad and some marriages unhappy, this is not generalized in any way. The parashah also provides a unique explanation for the posteriority of the creation of Eve in Genesis 2. 'And why didn't He create her for him to begin with? The Holy One, Blessed be He, foresaw that he (man) would complain about her, ${ }^{37}$ hence He did not create her until he specifically asked for it with his own mouth' (17:4). To paraphrase, God foresaw misogyny, and hoped He could nip it in the bud. The scenario dreaded by the divine mind soon unfolds in the biblical text, when Adam rushes to blame both the woman and God for his own eating of the forbidden fruit: 'The woman whom you gave to be with me, she gave me fruit from the tree, and I ate' (Gen 3,12). Unfortunately, the divine counterargument: 'you asked for it' does not silence Adam, or other like-minded men, for all eternity. Nevertheless, the midrash saw fit to note or rather invent this divine attempt to stop men from blaming women for their actions, and defining them as equals. ${ }^{38}$

Thus, the tone of the parashah is set: first, we witness that women were created equal, as part of the original plan. Second, a link between the creation of Eve and all womankind is formed. Third, the words 'ezer kenegdo' are interpreted in line with Biblical Hebrew to mean 'with him', and thus all the blessings of man are portrayed as whole only with 'her'. Fourth, we learn that the blessing is meant to be universal, for those less fortunate whose blessing turned into a curse, a way to undo the curse and find blessing is offered - in the form of a divorce bill. ${ }^{39}$ There is no hint here of a misogynist reading of the verses, or of women's inferiority. It is important to bear this in mind, if we assume that the parashah is carefully edited. While tones may change, first impressions are important.

\section{The Carnival of the Creation of the Second Man}

The next sign of the parashah, which follows almost immediately, starts with a series of interpretations of the verse which launched a thousand poisoned pens: 'and he took one of his ribs and closed up the flesh instead thereof' (Gen. 2:21)."

\footnotetext{
${ }^{36}$ Which is made possible as in Gen. 1-3 the same word, 'man', 'Adam', denotes both the male human and the human race.

${ }^{37}$ The Hebrew here, 'likro tigar' is hard to translate. It may as well be translated as to cry out that God is not treating him fairly because of her; to defy her; to blame her/play her prosecutor.

${ }^{38}$ This understanding of men as people who, instead of looking inwards and looking for their own bad behaviour, blame women for everything, is repeated in another interpretation of this verse both in Pesiqta de Rab Kahana Vatomer Zion 17:3 and in Lam. Rabbah 3:39 (Buber).

${ }^{39}$ The fact the rabbi Yose of Galilee supports his former wife even after their divorce might testify not only to his goodness of heart, but also to the fact that she was his niece to begin with. Hence, that her being "his flesh" in the verse quoted, "and that you do not hide yourself from your own flesh" (Isaiah 58:7) is due to her being his relative, not his (ex-) wife.

${ }^{40}$ Since NRSV here chooses a translation which does not reflect the ambivalence of the Hebrew, I followed in this case King James (KJV). On this verse's role in defining marriage in Christianity see: Elizabeth A. Clark, "Dissuading from Marriage: Jerome and the Asceticization of Satire," in Warren S. Smith, ed., Satiric Advice on Women and Marriage: From Plautus to Chaucer (Ann Arbour: University of Michigan Press, 2005), 170-2.
} 
The very bodily aspect of this verse, which stands in opposition to the swift, tidy creation by speech acts, marks the beginning of the parashah's movement from the serious to the comic and back. How exactly is a whole woman made out of one rib? And what are the consequences? Those two questions have been asked time and again from this point onwards.

At first sight there's nothing comic about the interpretation of the verses to come. It is only when their structure becomes evident, that we can see the tension between form and content, between the serious and the comic. This is manifested in the dialogue not only of the interlocutors, but also in the voice of the text, or rather its double voice. As we have learned from Griswold, the hand of the editor (Plato in his case), and Platonic irony materialize, among other means, by repetitions and choice of character. The next longer textual unit in our parashah is an editorial tour de force, as it offers us multiple mini-structures of doubling, repetitions, and odd choices of rabbinic interlocutors.

Rabbi Shmuel bar Nachmani said: one of his sides, in line with the verse: "And for the second side of the tabernacle on the north side” (Exodus 26:20).

And Shmuel said: He took one rib from each pair, as it does not say 'and closed up the flesh instead of it', but 'instead of them'. (Gen. 2:21)

Rabbi Haninah son of R. Adda said: from the beginning of the book to this passage the letter S (Samech) is not written. But as the woman was created, Satan was created with her. And if someone should say to you: 'that is it which compasseth' (Gen. 2:11), tell him that this verse speaks of rivers.

And closed up the flesh instead thereof (Gen. 2:21)

R. Haninah bar Yitshak said: He made an adornment to his bottom, so he should not be disgraced as a beast is.

Rabin said: there was a dispute between Rabbi Yanai and Rabbi Yanai. One said: He made him a lock and a footstool protecting it, so he would not suffer when he sits down.

And the other said: He made him cushions.

Rabbi Illa and Rabbi Immi [had a dispute about the same verse]:

One said: He provided burial for him.

The other said: He provided him with shrouds.

The first unit starts with a representation of a dialogue between two interlocutors, oddly carrying the same name, Shmuel. The two are rather easily identified. The first is a second/third-generation Palestinian amora, Shmuel bar Nahmani, and the second may be one of three other possible Shmuels." They argue not only over the meaning of the word zela, rib, but on the nature of the operation God performs on the primordial human. According to the first Shmuel, who interprets rib to mean side (on the basis of a prooftext from Exodus, and the midrashic technique of Gezera Shava), we are witnessing something in the realm of the separation of the first human created in Genesis 1 and attested in Genesis

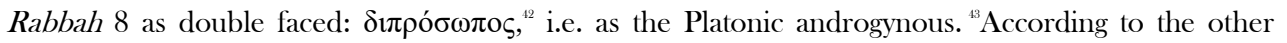
Shmuel, God took ribs from both sides of Adam's body, or from between each pair of his ribs, i.e. indeed creates Eve from the bones and flesh of a normal human being, who was created man and male."

\footnotetext{
${ }^{41}$ Shmuel, known from the Bavli, left Palestine in the early third century, but may still have been quoted. Shmuel bar Natan is contemporary and R. Shmuel bar Immi is a bit younger (fourth generation). The name of both Shmuels, in any case, is stable in all the manuscripts of Genesis Rabbah (apart from MS Munich, which has "bar Nahman" instead of "bar Nahmani").

${ }^{42}$ Plato, Symposium, 189d-189e. This is a repetition of a tradition quoted in Gen. Rab. 8: 'R. Shmuel bar Nachman said: when God created the first human, he created it double faced, and he sawed it [in half], one back here and one back there. They argued against him: 'and he took one of his ribs (Gen 2:21), and he said: from his side, as it is said: "And for the second side of the tabernacle צלע המשכן (Ex. 26:20).”

${ }^{43}$ I use here the term androgynous as in Plato's Symposium and not as the norm in rabbinic literature (i.e. a real person born with both male and female genitalia, hermaphrodite), because this is precisely the creature that Plato describes.

${ }^{4}$ A similar argument as to the understanding of the mechanics of creation appears in BT Berakhot 61 a, and discussed by Rachel Salmon and Gerda Elata-Alster, "Retracting a Writerly Text: In the Footsteps of a Midrashic Sequence on the Creation of Male and Female," in Ann Loades and Michael McLain, eds., Hermeneutics, the Bible and Literary Criticism (London: Macmillan, 1992), 1903.
} 
While this argument may still have grave implications, and look serious enough, the next midrash, that of Rabbi Haninah, plays a variation on the same theme, this time more explicit, wicked, and funny. Rabbi Haninah argues that the letter samekh, ' $O$ 'appears for the first time in the Bible in this verse (in the word ויסגר, 'and He closed'), which signifies the creation of Satan alongside woman, as his name begins with the sound 's'. This highly misogynist midrash of letters is revealed as a bit dubious even before it is directly contested in the text. In Rabbinic Hebrew the letters 'sin' and 'samekh' are homophones but not homographs. Satan indeed starts with the sound S, but not with the letter samekh, making Haninah's little pun into no more than just that. ${ }^{45}$ In a culture that learns a mountain of laws from every dot in the Bible, this play with kri and ktiv is extraordinary. While there are many cases in which the rabbis suggest reading aloud (kri) which is different from the letter, this is a unique case when we are called both to notice the difference and to make nothing of it. The objection which the text itself brings against this drasha completely ridicules it. It shows that both the letter samekh, and the sound S, indeed appear before the creation from the rib, in a verse which refers to one of the rivers of paradise. The answer that one must give to such a 'doubting Thomas' is quite lame. It argues that the verse speaks about rivers, not humans or animated beings, and is therefore irrelevant. The refutation is weakened by Genesis Rabbah itself, in a passage quoting the same R. Shmuel Bar Nahmani and Hanina, which ascribes the creation of hell, dispute, and all things bad to the second day of creation, ironically, the day in which water was created (Gen. Rab. 4:7). Traces of Socratic irony, at once stating a thing and its opposite, at once false and true, are starting to emerge, alongside markers of Platonic irony, like drawing attention to the gap between the oral and written elements of the text. ${ }^{46}$

The next unit focuses our attention on the process of interpretation, and the place of ideology within it. Arguments, such as those which appear in Leviticus Rabbah 14:1," that the last to be created is the least important, or that woman was not part of 'the original plan of creation', are based on the secondary creation of woman from man's already divinely created body. But those arguments seem to forget that Adam's final form was not actually determined until the creation of woman - his very own body changed. ${ }^{18}$ This little fact, however, does not escape R. Haninah, who seems to be in dispute with the other Rabbi Haninah (just mentioned) over the nature of women.

Haninah number two ${ }^{19}$ finds no difficulty in assuming that not only the shape of the female but also of the male body was not determined before the rib was taken from it. The creation of the human body as we know it was handcrafted by God, not only spoken by Him. God sculptures this new body into its perfect two forms. But what was this fundamental, even revolutionary change to the human body, the alteration that made us all who we are today? Excuse me if I bring up the serio-comic again, when I remind you that according to Haninah, it was no more and no less than the creation of the arse, our behinds, or 'the adornment of the bottom', in the language of Midrash. But this is no joke. If we accept the assumption of the first Shmuel, that God separated the two parts of the androgynous, which was attached at the back, as we learn from Plato's symposium, the creation of the arse is indeed necessary. If we accept the second Shmuel as the spiritual father of the second Haninah, then the completion not of the human body, but of the male body follows that of the creation of Eve, i.e. man and not woman was the last to be created, as an afterthought of an afterthought, if you will.

A ridiculing of both midrashic and misogynistic logic is starting to crystalize/take shape, when a third pair in a row of rabbis carrying the same name appears, disputing the exact nature and form of

\footnotetext{
${ }^{45}$ It is nice to see how this Midrash gives itself away, whether it is orally performed or silently read. In case of its oral performance, one would have to choose between naming the letter Samekh or Sin, and in case of a read text - whether to write one or the other. In both cases the audience feels the inconsistency.

"Griswold, "Irony," 95.

${ }^{47}$ This idea may also be found in Tanhuma Aharei Mot 9 (Joshua's dispute with the Sun) and Ex. Rab. 21:6 (Moses and the Sea).

${ }^{18}$ On the first man as a completely different being, whose form does not resemble that of Adam and Eve in Gen. Rab. See: Virginia Burrus, "Carnal Excess: Flesh at the Limits of Imagination," Journal of Early Christian Studies 17/2 (2009): 257-60.

${ }^{49}$ In the case of the Haninahs, the name game is a bit more difficult. The name itself appears in rabbinic literature as Haninah, Hananah, Hinanah and in other spellings. The good manuscripts have, instead of Haninah bar Ada, Haninah bar Eha, a secondgeneration amora (Vatican 30, Oxford 147, Paris 149). Haninah Bar Yizhak appears only in Genesis Rabba, once in the Yerushalmi and once in Leviticus Rabba, and is thought to be a third-generation amora.
} 
the novel human's behind. Divine grace, expressed in separating not man and woman, but man and beast, by virtue of hiding the anus at the time it passes stools, is what separated by R. Yanai and his fierce opponent, marked as such by Vav Hanigud, his mysterious doppelganger, Rabbi Yanai. ${ }^{\text {so }}$

Rabbi Yanai the first insists on the creation of the anus, which is like a lock, and on top of it a little seat, or footstool, ${ }^{\text {si }}$ both of which were installed on the occasion of the creation of Eve. Rabbi Yannai the second,${ }^{52}$ however, insists that the last act of creation was not wasted on the anus, but on the buttocks, the rear pillows of humanity which were created on that day. I fail to see the difference between the footstool of R. Yannai and the cushions of R. Yannai which justified quoting their dispute. ${ }^{53}$ By now, it is difficult to escape the playful tone of the midrash. The doubling, the hatred, the word games, the bottom, the adornment of the bottom, control, lack of control, mercy are all at play here. Man's nothingness in comparison to God, the fear of the vulnerability of the male body, of men's bodies, are all suddenly present, and the horror is met with laughter. As Mikhail Bakhtin taught us, in the logic of carnival, the eternal, the metaphysical, de profundiis are mediated through the flesh. ${ }^{\text {st }}$ The mythical, awe-inspiring moment of the creation of man, and of the patriarchal and androcentric social order is mediated here through word and name games, norm breaking, and bringing our backside to the front. To turn the second creation narrative of humanity into a discussion of our defecating apparatus is well within the logic that Bakhtin identified as the 'logic of the upside down'. Bakhtin taught us that the carnival entails constant movement, and interchange of the holy and the profane, the sacred and the defiled, the spiritual and the carnal. Ambivalence is the carnival's weapon of choice: at once humiliating and destructive, almost deadly, and reviving, resurrecting, and rebirthing. Its imagery is made of the lower strands of the body: the belly, the sex organs, the anus, and the creation of the link between sex, food and birth. ${ }^{53}$ Special attention is given to the organs that are opened to the world and to what goes into and out of them: the mouth, the anus, the breasts, the sex. The human body of the carnival is open, not finite. It is always still being created, stretched between birth and death. ${ }^{36}$ The carnival is strongly tied to the earth and to the body, as they are one, as Genesis 1 taught us. The earth swallows like a hungry mouth or a grave or a womb, but also revives, and gives birth, and nurses. No wonder our next pair of Rabbis creates the link between the first man and earth not only in the time of birth but in the time of death.

Rabbi Illah and R. Aimi, whose names sound in Aramaic like Rabbi Rib (Il'ah) and Rabbi My Mummy (Immi, as he is often called in the Yerushalmi), wish to interpret 'and he closed up the flesh thereof' as referring not to the creation of life, but of death. According to Rabbi Illa, also known as 'the Rib', God installs burial on this occasion (for dust thou art, and unto dust shalt thou return (Gen. 3:19)), which makes death part of the divine plan prior to the fall. Burial reverses the creation in returning any human flesh to the primordial body of the first man: the earth. Humans are free of the earth, as long as they live. But just so we do not lose ourselves in a cyclical mythical logic, R. Aimi/Immi suggests that, at

\footnotetext{
${ }^{50}$ Thinking about the Platonic myth as it already appeared in the parashah, and again in Genesis Rabbah, it is hard not to see the three couples of rabbis carrying the same names as split creatures themselves, who function more as alter-egos than those Aristophanes saw as a primeval man cut into two men.

Jastrow offers to read here the Greek hupopodion, i.e. saddlecloth, and not efippion, footstool, but the text which refers to preventing humankind from suffering by sitting on an exposed anus makes the creation of a 'built-in' seat more reasonable. Marcus Jastrow, Dictionary of the Targumim, the Talmud Babli and Yerushalmi, and the Midrashic Literature (Peabody, Mass.: Hendrickson Publishers, 2005), 101. Daniel Sperber, Material Culture in Eretz Israel During the Talmudic Period, vol. 2 (Jerusalem: Yad Izhak Ben Zvi Press, 2005), 74-6 [Hebrew], suggests a portable leather seat/box one could sit on, which would be logical in our case.

${ }^{52}$ We know only of one R. Yannai, a first-generation amora, who would make sense in this context. The second Yannai is a complete mystery. Vatican MS 30 offers no help, as the word there is corrupt, Oxford MS 147 has R. Yoni but this rabbi is nowhere else to be found. The parallels of this drasha in other compilations have many different variants, as Albeck has already noticed: R. Yohanan, R. Yuden, R. Illa and R. Ami. He concludes that it is not likely to be R. Yannai Zeira and R. Yannai the son of R. Yishmael, but cannot explain Rabin here (Genesis Rabbah (Theodor-Albeck), 157). My suggestion, that this is a 'special feature' inserted by the editor of the parashah, solves the mystery.

But let us not underestimate the task of giving form to the human body. From talmudic times, Jews blessed God daily for the sophistication of the human body, for creating it in such wisdom so what needs to be opened is opened and what needs to be closed is closed, a blessing said for centuries every time a human uses the toilet (Birkat Asher Yatzar; BT Berakot 70b).

${ }^{54}$ Bakhtin, Rabelais, 19.

${ }_{55}^{5}$ Ibid, 21-5.

${ }^{56}$ Ibid., 26-7.
} 
this moment, God also created the shrouds, a tiny wedge which separates the dead body from the earth that gave birth to it, between the first creation of the earth and human procreation - flesh to flesh, flesh from flesh. A thin cloth to remind us of God's place in the process. In both cases, burial is the supplement of the rib, in all of its Derridian sense: both an addition and a substitution. ${ }^{37}$ It is with the creation of the final form of the human body that it becomes mortal, and indeed fully human, as noted by both 'parent Rabbis' Rabbi Illa and Rabbi Immi. If death is created before the Fall, and is the very last act of creation, then the rib, the human body, now supplements the earth as creator. At death not only man and earth become one, but also man and woman. The rib, taken from the body which was created of earth, is finally returned to the primal mother. Her burial makes Adam and Eve one body once more, within the greater body of the earth. The dichotomy of male/female finally collapses. The earth, as Bakhtin shows, is the great equalizer, and as such it is celebrated in the carnival. Within the carnival's logic, this brings joy, rather than pain.

This dramatic moment in the parashah marks the end of the mythical narrative of creation. From this point forth, the doppelganger rabbis cease to appear, and the narrative shifts from the creation of the first man and woman to ordinary human beings. The focus moves to the relationships which are created in the triad that occupies the earth: man, woman, and God. This is also the point at which woman comes to represent all women, and man all men.

But the doubling game is not abandoned quite yet. Next, the parashah offers us a new kind of dyad, two stories of the same genre (Ma'ase Hakhamim). The first is far more interesting than the second, as it serves two masters: it is both an exegesis of scripture (homily) and a story (i.e. classified as Sippur Darshanl), ${ }^{s i}$ which has the interpretation of the Bible as its theme.

For the first and last time in this parashah we hear a different voice: the actual voice of a woman. Matrona asks Rabbi Yose, 'why by means of theft [was woman created]?' referring to the fact that Adam did not know what was about to happen, or consented to the operation about to be performed on him. Why did it all have to happen when he was asleep? Could the first theft in the world be blamed on God instead of on womankind? Rabbi Yose answers Matrona with a parable, one which is very well known in contemporary Palestinian rabbinic literature. In other contexts, it serves to laud God's intervention in the creation of each and every human being, not only the first couple. In Leviticus Rabbah 14, this parable celebrates the wonders of conception and birth, the miracle of the transformation of a drop of semen into a whole human being, with perfect body and soul. ${ }^{59}$ Derrida's supplementary logic returns: Eve here, like any other human being, is created as a supplement which replaces that which was deposited with something else: bigger and better, but not similar. But Matrona is no fool; she keeps her eyes on the facts: Adam did not deposit anything out of his own free will, and giving a person something different from that which was unwillingly taken from him, even if more valuable, is hardly doing right. The second answer of R. Yose enters a deeper, darker realm. God had to put Adam to sleep because the first woman and her creation process were disgusting, or rather, because Adam could not be trusted with seeing beyond the flesh. When Adam saw the first woman created out of his body, he was not able to do what every woman who ever gave birth to a baby does: ignore the blood, the vernix, and the other bodily fluids with which the new-born is covered immediately after birth, and see the lovable, cuddly and nice-smelling being it will become after the miracle of the wiping of the baby with a cloth will occur. God is indeed a merciful God, and treats Adam like a child. In order to enable him to repress his anxieties, he uses general anaesthesia instead of epidural for his rib-section. In a way Rabbi Yose wins the

\footnotetext{
${ }^{57}$ Jacques Derrida, Of Grammatology, trans. Gayatri Chakravorty Spivak (Baltimore; London: Johns Hopkins University Press, 1997), 144-5.

${ }^{58}$ Ofra Meir, The Exegetical Story in Genesis Rabbah (Tel Aviv: Hakibbutz Hameuchad, 1987) [Hebrew]; Joshua Levinson, The Twice-Told Tale: A Poetics of the Exegetical Narrative in Rabbinic Midrash (Jerusalem: Magnes Press, 2005) [Hebrew].

59 Galit Hasan-Rokem, "Conception, Pregnancy and Birth in the Rabbinic Imagination of Leviticus Rabbah 14: Preliminary Remarks," in Israel Bartal, Galit Hasan-Rokem, Ada Rapoport-Albert, Claudia Rosenzweig, Vicky Shifris and Erika Timm, eds., A Touch of Grace: Presented to Chava Tumiansky (Jerusalem: The Zalman Shazar Center, 2013), 393-422 [Hebrew]; Tali Artman, Dialog, Mitos ve-Yitzug Demui Historia: Keria be-Shiv'a Mifgashim Bein Matrona le-R. Yossi be-Bereishit Rabba, MA Research Paper, Hebrew University, Jerusalem (2002), 58-71 [Hebrew].
} 
argument. He succeeds in conveying to Matrona the necessity of Adam's sleep and God's actions. She now agrees that indeed God had to act in secret. But unlike Rabbi Yose, who blames this on the repulsiveness of the first woman, Matrona blames it on the short-sightedness not only of Adam, but of all of his male decedents. Her uncle had made a worse choice of wife because, just like Adam, he refused to acknowledge similarity and familiarity between men and women as a positive thing and see the beauty of his niece, herself. Matrona understands this as a refusal on his part to accept his own human nature, his history as a filthy new-born. And so it is Matrona, a woman, who creates the link between everyman and Adam, everywoman and Eve.

The second Ma'ase hakhamim again exposes the shortcomings of men, this time as ethical beings. While men are portrayed as ethically spineless, women are ascribed superpowers. They have the power to transform men's lives, to bring about salvation. ${ }^{60}$ But if you sense a snake in this grass of praise, you are not mistaken. This praise of women is a double-edged sword. If women control men, then Adam was right in his complaint about the woman.

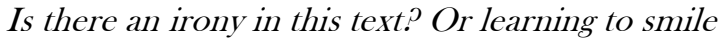

I believe, just like Boyarin, that the use of double-voiced speech expresses intellectual dissatisfaction with the world and with the philosophers contradictory views of it lead to a desire to get to the truth directly. ${ }^{\text {,il }}$ The next (and last) unit is perhaps the most paradoxical and most interesting of them all. I see in it the crown of the literary and moral achievement which is parashah 17, much as opposed to Boyarin and Baskin, ${ }^{62}$ who saw it as the most misogynistic text in rabbinic literature. I suggest, that in line with the carnivalesque tone of the entire second half of the parashah, and its tendency to expose the stupidities which serve as the foundation stones of misogyny, this last part may be read as ironic and comic at least as much as it can be read as serious, if not more. Its elaborate stylistic design and editing, its playful and twisted intertextuality, its immediate context and its uniqueness in the corpus, mark it as the climax of the parashah.

The eleven question sequence, which ends the parashah, has no full parallel. Parts of it, however, are dispersed across the body of rabbinic literature. The last three questions appear as a single unit, though not as questions and always with a slightly different meaning in YT Shabbat (2:6) 20a, BT Shabbat 31b-32a and more. ${ }^{63}$ A version of questions 1, 3, 4, and 5 asked of R. Dusati son of Yanai, appear in a Baraita quoted only in BT Niddah 31a, and the exegesis of Genesis 3:16 is paralleled in the list of the ten curses of Eve found in BT Eruvin 100b, and the practically identical Avot de Rabbi Nathan (ADRN) A, 1:7 which resemble our questions 5, 6, and 8. To this we might add ADRN B, 9, the closest parallel to our unit.

The eleven question sequence, then, is the work of the editor of Genesis Rabbah, whether he is quoting or being quoted by the others. Since Rabbi Yehoshua is also not mentioned anywhere in the context of this specific content, we must ask what the editor gains by using his character. The Platonic mode re-enters our discussion, when we ask why Rabbi Yehoshua was chosen here. R. Yehoshua offers the text a unique combination of traits: he is one of the only sages whose mother is praised as responsible for his wisdom (YT Yevamot (1:6) 8b); he is the regular bar plugta - discursive rival of R. Eliezer, the man who preferred Torah to be burned rather than given to women; $;{ }^{61}$ but mostly, and especially in Genesis Rabbah itself, he is known for arguing or rather answering a collection of rabbinic Others and their representatives: From Hadrian (Gen. Rab. 10:3; 28:2, 78:12) to a philosopher (20:4), a non-Jew

\footnotetext{
${ }^{60}$ The exact opposite is argued by John Chrysostom who thinks that men are responsible for how 'good' women are, and therefore should dominate them (John Chrysostom, Adversus Iudaeos 2.3.4-2.3.5 PG 48, 860-1). See: Susanna Drake, Slandering the Jew: Sexuality and Difference in Early Christian Texts (Philadelphia: University of Pennsylvania Press, 2013), 90.

${ }^{61}$ Boyarin, Socrates, 26, 132, 202.

${ }^{62}$ Boyarin, Carnal Israel, 88-90; Baskin, Midrashic Women, 66-9.

6a Tanhuma Noah 1; Kohelet Rabbah 3:3; ADRN B, 9.

${ }^{64}$ YT Sotah (3:4) 16a.
} 
(13:6), and a group of heretical Jews (YT Sanhedrin (7:13) 4b). Unfortunately, it is only in the Bavli that an account of R. Yehoshua's physical ugliness is given. If a story about an ugly man who engages in dialogue and somehow always wins sounds a bit familiar to you, it is not my fault. Genesis Rabbah chooses, then, a persona with high authority, with a reputation of being a biblical scholar (Gen. Rab. 64:29), ${ }^{65}$ and who marks the boundaries of faith. It also chooses a person who is long dead, and therefore a dramatis persona easier to manipulate. ${ }^{66}$ But who asks the questions? In Genesis Rabbah, the formula that starts our story ( $\mathrm{X}$ asked of rabbi $\mathrm{Y}$ ) always specifies who $\mathrm{X}$ is/are. In the Tosefta, when someone is being posed questions by persons unspecified, we are to assume that it is the rabbi's students who are asking. But given the reputation of R. Yehoshua as a man who answers the questions of those who do not know or reject rabbinic 'truth', and refutes their arguments as stupid, we may assume that he is more a literary character than an historical figure here. We would expect, then, R. Yehoshua to refute the arguments or negate the validity of the questions of the mysterious askers. This isn't the case. Instead, what we have in this highly stylized unit is a repeating structure and logic: (a) a concrete question about a piece of 'trivia' about women is posed to Rabbi Yehoshua, presented as a fact, (b), which is not always (or at all) trivial. (c) He answers in the form of a parable, (d), which blames everything and anything on Eve. (e) His answers are never contested, and the Bible is never quoted.

Is it possible that R. Yehoshua is being ironic? That he, or rather, the editor of Genesis Rabbah, plays a little game that goes over the heads of the people who ask the questions?

The first question is already an example of this problem:

1. Why does a man come forth with his face down and a woman with her face up?

He told them: the man looks to the place from which he was created, and the woman to the place from which she was created.

To the best of my knowledge, and also to the best of ancient medical knowledge, female and male babies are not indeed born facing up or down respectively. While this is completely ridiculous, it is accepted as a fact by Rabbi Yehoshua, and later rabbinic sources even see it as a piece of wisdom revealed in Egypt to the Jewish midwives Shifra and Puah (BT Sotah $11 \mathrm{~b}$ and $E_{x}$. Rab. 1:14). ${ }^{67}$ The closest parallels to our text, however, are found in ADRN B, 9, and in BT Niddah 31b, and tell a slightly different story, which makes much more sense. There, women face up and men face down during sexual intercourse, not at the time of being born. Re-enacting creation in the time of creating a new life operates with perfect logic. This is but the first of many examples in this list of dictums that are presented as seriocomic in Genesis Rabbah become crystal clear and as grave as death in the parallel sources. The process of trying to do away with ambiguity and tension, of trying to decide whether a text should be taken seriously or not, seems to lean, over time, to the serious side. So much so that a late midrash (Midrash Aggadah, Buber on Vayikra Shmini-Tzria 12:6) provides us with the explicit explanation of the missing link between our fake fact and the normative sexual positions of its time: boys and girls are born looking up and down because of the position of men and women during intercourse. What was meant to be a pun, or a slightly dirty joke, or a fake fact ${ }^{68}$ in Genesis Rabbah turned into something completely different in all the other sources.

\footnotetext{
${ }^{65}$ Theodore-Albeck, II, 712.

${ }^{66}$ On folklorizing tannaitic rabbis in amoraic literature (albeit Babylonian) see Galit Hasan-Rokem, "Did Rabbinic Culture Conceive of the Category of Folk Narrative?" European Journal of Jewish Studies 3/1 (2009): 19-55.

${ }^{67}$ And thus save the baby, as Pharaoh had only ordered them to kill boys. If they knew the sex of the baby before it was completely out, they could leave the room and not witness the birth of a boy - and be obliged to kill him.

${ }^{68}$ Or perhaps, an alternative fact, as some may put it. In the most women-fearing texts of the ascetic movements, anyway, we find a reverse trope: women must look down in shame at all times. See Susan Ashbrook Harvey, "Women in the Early Syrian Christianity," in Averil Cameron and Amélie Kuhrt, eds., Images of Women in Antiquity (London: Croom Helm, 1983), 295-6.
} 
2. And why must a woman wear perfume and a man must not?

He told them: Man was created from the earth, and the earth never stinks, but Eve was created from a bone.

Here is a parable: if you leave meat for three days without salt, it immediately stinks.

The second question is again a fake fact. It transforms a habit, a choice made by both men and women in late antiquity to perfume themselves, into a mandatory action and obligation for all womankind. ${ }^{69} \mathrm{I}$ have searched both oral and written Torah for the commandment of wearing perfume, or the punishment of the Lemnian women, ${ }^{70}$ but alas, did not find it. Rabbi Yehoshua's answer is even funnier than the question he was asked. It plays with the Greek Pandora myth and with some Christian adornment fearers, ${ }^{71}$ as it turns an adornment into camouflage, and reality (both experienced and textual) on its head. Men, as opposed to what some of them may think, do stink. I am not basing this only on my personal impressions, collected over many Israeli summers; rather, rabbinic literature itself holds knowledge of this. Indeed, the bad smell of sweat is one of the curses by which Adam (but not Eve!) is cursed after the fall. ${ }^{72}$ The smelliness of women is explained by a rather fishy parable. Unless we truly believe that all mankind's flesh is made of earth, and that women have no flesh at all since they are all bones, it is rather difficult to accept the analogy. If that is not enough, the very assumption that women are odorous because they are made of flesh is turned on its head in question number four in the sequence. There, we learn that bones do not absorb water/rot, i.e. do not smell. I believe that what we have here is more of a parody of misogynistic biblical interpretation and of misogyny itself than a real argument about the smelliness of women.

In later versions of this story, and in ADRN B, 42, women must adorn themselves in order to remain attractive to their husbands, ${ }^{73}$ following the logic already manifested earlier in the dialogue between Matrona and Rabbi Yose. Men can be forgiven for not adorning themselves both because women are not so influenced by first sight (or rather smell), and because they have no other choice of sexual partner but their husband. ${ }^{7}$ There may be many bones to choose from, but only one earth.

ADRN shows again the turning of the seriocomic, the grotesque, or the absurd into logical, rational, and un-ambivalent expressions.

3. And why does a woman's voice travel far, and a man's does not?

He told them: here's a parable: if you fill a pot with meat, the sound of the pot does not travel, but if you put a bone in it, instantly its sound will travel.

The third question places women in the kitchen, the place where patriarchy has long argued they belong. However, they are not the cooks, but the cooked. The fake fact, or un-trivial trivia here is that women are louder than men, or in the Hebrew 'their voice goes forth/travels'. Reality teaches us that the only true argument to be made about women's voices is that they are generally more high-pitched than men's. ${ }^{75}$ The parable turns again to the imagery of flesh and bone. The bone from which women were made

\footnotetext{
${ }^{69}$ Men's habit of wearing perfume is well attested. See Constance Classen, David Howes and Anthony Synott, Aroma: The Cultural History of Smell (London and New York: Routledge, 1994), 17, 35-36; Susan Ashbrook Harvey, Scenting Salvation: Ancient Christianity and Olfactory Imagination (Berkeley: University of California Press, 2006), 41. Both Clement and Tertullian refer to men wearing perfume (Clement, Christ the Educator 2.8.66 trans. Wood, 151-152; Tertullian, The Apparel of Women, 1.2), while male cultus separates the noble Roman citizen from the "wild man', women get bashed for perfuming by Juvenal: Maria Wyke, "Woman in the Mirror: The Rhetoric of Adornment in the Roman World," in Léonie J. Archer, Susan Fischler, and Maria Wyke, eds., Women in Ancient Societies: An Illusion of the Night (Basingstoke: Macmillan, 1994), 135-7.

${ }^{70}$ See Eva Cantarella, Pandora's Daughters: The Role and Status of Women in Greek and Roman Antiquity, trans. Maureen B. Fant (Baltimore: Johns Hopkins University Press, 1987), 35. But even the foul odour of the Lemnian women was only a temporary punishment, for defying Aphrodite, i.e., taking seduction too lightly.

${ }^{71}$ The adornment of women is a well-known comic trope by the time of Genesis Rabbah see, Clark, Dissuading, 160-1; Jerome, Adversus Helvidium, 20. However, it comes from a tradition which negates marriage, hardly something the Rabbis wish to do.

${ }^{72}$ ADRN B 42

${ }^{73}$ Michael L. Satlow, Jewish Marriage in Antiquity (Princeton: Princeton University Press, 2001), 236.

${ }^{74}$ Men may take a second wife.

${ }^{75}$ Aristotle didn't miss a chance to make this into a marker of female evil disposition. Brave creatures, unlike them, have large deep voices. See: Anne Carson, "The Gender of Sound," Thamyris 1: 10-31, 1994 (esp. 10).
} 
rattles in the pot, unlike the boneless Mollusca, the man, who makes no sound. In addition, the mashal does not correspond to the nimshal: If the woman is a bone and the man flesh, what is the pot? The bone seems to turn into a comic leitmotif much like the little oil flask ${ }^{76}$ which Aeschylus argues he can add to any line of Euripides, and indeed does, in Aristophanes' The Frogs." Reading with the phallic oil flask in mind, we can think of a situation in which a 'bone' enters 'flesh' and makes it noisy. So can the rabbis: According to Mishnah Ketubbot 7:6 and its interpretations in YT Ketubbot (7:6) 31a-b and BT Ketubbot 72b, a man can divorce a woman without paying her Ketubbah if she is very loud (Kolanit), presumably while having sex. ${ }^{78}$ The voices that women make are marked as 'bad' in rabbinic literature as and when the upper and the lower labia are connected. ${ }^{79}$

The experiment of cooking men steak and women bones turns into an even dirtier joke. ${ }^{80}$ But even with this obvious quip, when there is a will to make it serious, there is a way. ${ }^{81}$ In a parallel to four of the eight questions asked here in BT Niddah 31b, the question asked is why are women's voices more pleasant than those of men, a questioned answered by a quote praising Shulamit's voice from Song of Songs 2. This is another example of the way in which the ambiguity preserved in Genesis Rabbah is solved: either by making it 'better', more favourable for women, or worse as we have seen before.

4. And why is a man easily tempted and a woman is not?

He told them: man was created from the earth, and as soon as you pour a drop of water on it, it absorbs it.

But Eve was created from a bone, and even if you soak it for days in water, the bone does not absorb it.

By now, we ourselves have come to take for granted the difference of nature between men and women, based on the two different 'natures' of their creation. Any memory of this narrative as being but one option of reading the genesis of mankind among many has been wiped out of our minds. Perhaps this is what makes the next question so full of irony and playfulness. The discussion of temptation in the context of the creation story could have been the opening call for women-hunting season. ${ }^{82}$ But instead of what Satlow and Rosen-Zvi point to, that women in rabbinic literature are often on the side of temptation and not on the side which fights temptation, we get here an argument which makes women almost temptation-proof. ${ }^{83}$ We witness here, therefore, no less than an interpretative miracle. Eve, mother of all womankind, in whose footsteps it follows, was immune to temptation by her very nature. Put bluntly, Eve is the ideal rabbinic man, at least according to Satlow. ${ }^{84}$ The gap between the Bible, the seduction of Eve by the serpent, and the commentary here can swallow up some pulpits whole. And on top of this textual irony, the logic of the fake fact comes back. As plain logic has it, when a man commits adultery, a woman is involved in about 90 percent of the cases, which make women as likely to be tempted as men. The whole logic of the 'all women are (as bad as) Eve' trope, common in Jewish-

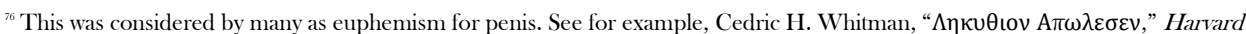
Studies in Classical Philology 73 (1969): 109-12. He makes the point that losing the oil flask is a nice way to say losing virility and becoming effeminate.

${ }^{77}$ Aristophanes, The Frogs, lines 1198-1250.

${ }^{78}$ The same complaint about women being loud during sexual intercourse is made by Juvenal, Satire 6, lines 64-65.

${ }^{79}$ See for example YT Hal. (2:1) 12b; BT Ber. 24a-b; BT Kidd. 60a.

${ }^{80}$ There is another option, preserved in YT Ketub. 7:6 (44b) as well, where a woman is blamed for being 'voicey' (kolanit), in a different way, speaking about matters of the house so loudly that her neighbours can hear, thus making the private public.

${ }^{81}$ An astounding parallel to this question is found in the thirteenth century: Jehan le Fe'vre, Lamentations de Matheolus, book 2 , lines 241-246: 'why are women more noisy, full of foolish words and more garrulous than men? Because they are made of bones and our persons are made of clay. Bones rattle louder than earth'. The translation is taken from: R. Howard Bloch, Misogyny, Misandry and Misanthropy (Berkeley: University of California Press, 1989), 18.

${ }^{82}$ See, for example Bernard P. Prusak, "Women: Seductive Sirens and Source of Sin? Pseudoepigraphical Myth and Christian Origins," in Rosemary Radford Ruether, ed., Religion and Sexism: Images of Woman in the Jewish and Christian Traditions (New York: Simon and Schuster, 1974), 97.

${ }^{83}$ Satlow, Jewish Marriage, 158-159; Ishay Rosen-Zvi, "Do Women Have a Yetzer? Anthropology, Ethics and Gender in Rabbinic Literature," in H. Kreisel, B. Huss, and U. Ehrlich, eds., Spiritual Authority: Struggles over Cultural Power in Jewish Thought (Be'er Sheva: Ben Gurion University Press, 2010), 21-34 [Hebrew].

${ }^{8}$ Michael Satlow, "Male or Female Did They Create It? Gender and the Judaism of the Sage," in Lee. I. Levine, ed., Continuity and Renewal:Jews and Judaism in Byzantine-Christian Palestine (Jerusalem: Yad Ben-Zvi Press, 2004), 486-504 [Hebrew].
} 
Hellenistic and Christian writings, is mocked here. ${ }^{85}$ Since women are harder to tempt, the temptation must have been very, very powerful. In addition, even the fake fact itself is doubted, as we have learned in the parable in answer to question 2, that bones do absorb water - since they rot. But there is still something to gain for patriarchy: if women are indeed like bones that do not absorb water, men can sleep more quietly at night, and they can also continue sleeping well if they themselves are tempted. After all, it is in their nature. Later rabbinic sources, as well as scholars of rabbinic literature, found this passage to be a pretty big frog to swallow. They have offered two main strategies to widen the throat, which are, in essence, one. ADRN B, 9 and BT Niddah change the Hebrew l'hitpatot, to be tempted to l'hitpayes, to be appeased. Men, unlike women, are easily appeased, and our stubborn woman is safely hated again. ${ }^{86}$ This generates a contradiction even within the ADRN text itself in which Matrona is appeased in an earlier part of the segment. Others may argue that Genesis Rabbah might have used the Hebrew I'hitpatot, but actually intended the Greek (almost) homophone peitheo, ${ }^{87}$ to persuade. This explanation is indeed tempting, but not very persuasive, as all of Genesis Rabbah manuscripts have l'hitpatot, and the very clear distinction exists between these two words in it.

5. And Why does a man demand [sex] from a woman, and a woman does not demand from a man?

He told them: Here's a parable: it is like a man who lost an object that belonged to him. He goes in search of his lost object, but his lost object does not search for him.

Now that we have learned that men are more easily tempted, and Eve cannot be blamed for introducing the sex-sin combination, we are not surprised by the next question, which asserts that only men ask/demand sex from women, and not the other way around. Let us not forget that by the fourth-fifth century, the time of the editing of Genesis Rabbah, the comic topos of the married woman as a sexual predator, who lusts over (young) men was already well developed. ${ }^{89}$ Jewish marital norms which are mainly reflected in later and Babylonian sources are that men may explicitly ask for sex, while women only hint/secretly wish for it (unless they had three cups of wine)..$^{90}$ This is overturned in BT Eruvin 100b where it is argued that if a woman asks her husband for sex, their children born of that act will be greater than the men of the generation of Moses. In other words, even the rabbis know women do ask for sex. The ambivalence, or the plain irony in Genesis Rabbah, is nevertheless played through objectifying women: just as objects do not seek their owners, so the rib (woman) does not seek her owner (the body of man from which she was taken).

6. And why does a man deposit seed in a woman, and a woman not deposit [seed] in a man?

He told them: Here's a parable: A person looks for someone loyal to deposit with.

The next question is even stranger, as it has nothing to do with Eve, the second creation story or even misogyny. If at all, it is a crack in the wall of patriarchy through which it is able to look at itself. Why do men deposit their sperm with women and not the other way around? Ancient medical knowledge has it

\footnotetext{
${ }^{85}$ See, for example, the testament of Reuben, 5:1-4; John Chrysostom, Adversus Judaeos, 2. See also Drake, Slandering the Jew, 90. But on the way that the Babylonian Talmud constantly sexualizes and radicalizes the verses in Sirach that deal with women and temptation see also Tal Ilan, Integrating Women into Second Temple History (Tübingen: Mohr Siebeck, 1999), 155-74 (especially 165ff). She also notes that Palestinian sources that quote Sirach do not quote it with regards to women. For more on the subject see: John Levison, "Is Eve to Blame? A Contextual Analysis of Sirach 25:24," Catholic Biblical Quarterly 47/4 (1985): 617-23.

${ }^{86}$ And re-integrated into general Roman misogynistic trends, see Cassius Dio, Roman History, 7, 29, 2. Cassius Dio, Roman History with an English Translation by Earnest Cary and Herbert B. Foster (Cambridge: Harvard University Press, 1914).

${ }^{87}$ Halevi sees this use in Mishnah Ketub. 9:4: E. E. Halevi, Olamah shel ha-agadah: Ha-agadah le-or mekorot Yevanivim (Tel Aviv: Dvir, 1972), 251

${ }^{88}$ The closest we get in rabbinic literature to the Greek and the Hebrew functioning as almost synonyms is in BT Eruv. 100b, where the rooster is a model for derekh erez, as he appeases the hen before he penetrates her.

${ }^{89}$ Joshua Levinson, “An-Other woman: Joseph and Potiphar's wife - Staging Body Politics," Jewish Quarterly Review 87/3-4 (1997): 269-301.

${ }^{90}$ Kallah Rab. 2:8; ADRN A, 1:1; ADRN B, 9, BT Ketub. 65a, BT Eruv. 100b.
} 
that women, just like men, produce semen which is ejaculated during intercourse. ${ }^{91}$ So why do women safe-keep the male sperm (i.e. get pregnant) and not the other way around? The answer is that unlike men, who we have already learned have stronger sexual urges, and are more easily tempted, women are loyal human beings. ${ }^{92}$ Let us notice that the rib has completely disappeared from the discussion, and that the leitmotif of depositing has already appeared before: in the parable of Rabbi Yosi to Matrona. In the only instance in history in which a woman was born of a man's body, God, and not man, held the deposit, the rib. God and women stand therefore on the same side, as they now fill the role that God assumed in creation. While it is true, just like Bloch and Boyarin argue, that prediction of the form 'women are' or 'woman is' is already misogynistic, ${ }^{93}$ it is hardly a slander of women.

This again may be (and indeed is) reclaimed by patriarchy, when in BT Eruvin 100b all of the above are considered curses by which God cursed Eve after the fall: a woman's lust towards her husband, being prohibited from asking for sex, and only being allowed one husband at a time, which is what ultimately makes her more loyal than the polygamist man.

7. And why does a man come forth/goes out with his head uncovered and a woman with her head covered?

He told them: here's a parable: it is like a person who committed a transgression and is now ashamed before people. That is why she comes out covered.

The seventh question about women's hair is even more perplexing. First we must find out if women indeed covered their hair, second, if so, why, and third, who would connect veiling only with the 'sins' of Eve, which were no different, after all, from the sins of Adam. The practice of covering married women's hair as part of the marriage ritual was widespread in ancient Mediterranean societies. But it is not always clear if women continued to cover their heads afterwards to any degree. ${ }^{9 t}$

From Rabbinic literature we learn that the rabbis wished for women not to appear in public with Rosh Parua, literally, untidy hair. The interpretation of Rosh Parua in Mishnah Ketubbot 7:4 is important. While the Mishnah suggests that a married woman's appearance in public with Rosh Parua is a sufficient cause for divorce, it is unclear what the expression actually means. The Yerushalmi tries to resolve this by specifying different kinds of hairstyles or coverings that may or may not be used in different spaces. BT Ketubbot 72b is already far clearer: if men were to divorce their wives for not wearing head coverings in the way that the Rabbis wanted them to, no daughter of Jacob would remain married. What we mainly learn from this is that head covering was an issue, and one that had to do with sexual availability, as the verse that is normally quoted in the context of veils/special hair styles for married women is that referring to the Cohen manipulating the hair of the Sotah (Num. 5:18). Even when some sort of covering is discussed in the list of the curses of Eve (and her daughters), on two occasions hair is not mentioned (ADRN A, 1, BT Eruvin 100b), in one (Pirqe Rabbi Eliezer 14) no covering of any sort is mentioned, and only in ADRN B, 42, do we find a parallel to Genesis Rabbah.

Regardless of whether women of fifth-century Palestine covered their hair or not, the practice is described in our text as a form of punishment for the sin of Eve, ${ }^{9,5}$ not a social reality which is shared with the rest of the eastern, pagan, Roman provinces, as some argued, ${ }^{96}$ or as biblical precept which has nothing to do with Eve (as in BT Ketubbot 72a).

\footnotetext{
${ }^{91}$ See Aline Rouselle, Proneia, trans. Felicia Pheasant (Oxford and New York: Blackwell, 1998), 27-8; Rebecca Flemming, Medicine and the Making of Roman Women: Gender, Nature and Authority from Celsus to Galen (Oxford: Oxford University Press, $2000), 307$.

${ }^{92}$ Again the Babylonian Talmud thinks otherwise, and even information cannot be given to women for their safekeeping (BT Shabbat $32 \mathrm{~b})$.

${ }^{93}$ Boyarin, Carnal Israel, 94; Bloch, Misogyny, 4-5.

${ }^{94}$ Molly Levine, "The Gendered Grammar of Ancient Mediterranean Hair," in Howard Eilberg-Schwartz and Wendy Doniger, eds., Off with Her Head! The Denial of Women's Identity in Myth, Religion, and Culture (Berkeley: University of California Press, 1995), 76-130, and in particular pages $96,100-5$

${ }^{95}$ In a similar way to what happens in the church. See Peter Brown, The Body and Society (New York: Columbia University Press, 1988), 80-1.

${ }^{96}$ Levine, "Gendered Grammar," 104. For more on veiling, both in Jewish and Christian settings see Mary Rose D’Angelo, "Veils, Virgins and the tongues of Men," in Off with Her Head! The Denial of Women's Identity, 131-65; William Walker, "1 Corinthians
} 
I am almost tempted to read this question and answer as a parody on 1 Corinthians 11 , as Paul is the only other known Jew of late antiquity to tie together the veiling of women, shame, and Eve. But even he does not create a link between The Fall and veiling. The only Church Father radical enough for that, is the very radical Tertullian.

Paul's testimony is, however, interesting, as his praise of women's hair as glory in 1 Cor. 11:15 suggests that women's hair was seen in public. Paul also insists on covering women's hair only when they pray or prophesize (1 Cor. 11:5), suggesting they are unveiled most of the time. ${ }^{97} \mathrm{He}$ also ties veiling to shame, but in exactly the opposite way to Genesis Rabbah - it is shameful for a man to cover and for a woman not to cover 'For the man is not of the woman; but the woman of the man' (1 Cor. 11:8), women should not look like men. ${ }^{99}$ Paul's explanation for men praying uncovered and women covered is the second creation story alright, but sin is nowhere to be seen.

The only way to redeem Genesis Rabbah from a too-radical-to-be-true position is to argue that even in it covering is restricted to public appearances in funerals. Which connects us to the next question:

8. And why do they [women] walk first in front of the deceased [in a funeral]?

He told them: because they caused death to come into the world, that is why they walk first 'and all men drawn after him' (Job 21:33).

As always, both question and answer are doubtful. A very intriguing passage in YT Sanhedrin (2.4) 20b says: 'some say that it is a baraita that women walk first and then men, and some say it is a baraita that men walk first and women after them. He who said that women walk first - it is because they brought death to the world in the first place. He who says men first, it is for the sake of the honour of the daughters of Israel, so that they (men) would not stare at women.'

There is no interpretation of this dictum that is not problematic for women. Nevertheless, it destabilizes the 'fact' that women always walk first. And even if women indeed do walk first, then the explanation given might be different. First, because women throughout the ancient Mediterranean were responsible for public mourning, ${ }^{100}$ and funeral processions were almost the only opportunity for Jewish women's voices to be heard and for women to stand at the centre of attention as they chanted. ${ }^{101}$ They were also a locus for female subversion of inscribed male norms. ${ }^{102}$ The women's appearance and voice in funeral processions often made quite an impression on the male audience, binding together Eros and Thanatos, as Judith Baskin has argued. ${ }^{103}$ It may be worth mentioning, in light of the last question asked of R.Yehoshua, that men also covered their heads in funerals. ${ }^{104}$ But, more to the point, and a beautiful manifestation of irony, is the strange choice of prooftext here. This is the first time a biblical prooftext

11:2-16 and Paul's view Concerning Women," Journal of Biblical Literature [JBL] 94 (1975): 94-100; Cynthia Thompson, "Hairstyles, Head covering and St. Paul: Portaits from Roman Corinth," Biblical Archaeologist 51 (1988): 99-115. Most interesting in our context is L. Ann Travis, "But I Want You to Know...: Paul's Midrashic Intertextual Response to the Corinthian Worshipers (1 Cor 11:216), JBL 112 (1992): 231-46.

${ }^{97}$ The word Paul uses is the Greek 'akatakaluptos'- which is consistent with that found in the LXX and in Philo for 'unbound or loosened hair'. This suggests that Paul required women to wear no more than a headband or a special hairdo, not a full veil (see A. Padgett, "Paul On Women in the Church: The Contradictions of Coiffure in 1 Corinthians 11.2-16," Journal for the Study of the New Testament [JSNT] 20 (1984): 70).

${ }^{98}$ Reading Paul may also reveal the origin of the strange word "kefaletin" which appears in YT Ketub. (7:6) 44b as the Greek 'kefaleton' - of the head.

${ }^{99}$ See again Travis, "But I Want You to Know," 240-2.

${ }^{100}$ Galit Hasan-Rokem, Web of Life: Folklore and Midrash in Rabbinic Literature (Stanford: Stanford University Press, 2000$)$ ), 111. Corbeill develops the theory that Roman funeral rituals invert birth rituals, and thus explains the dominance of women in them: Anthony Corbeill, Nature Embodied, Gestures in Ancient Rome (Princeton: Princeton University Press, 2004 ), 70.

${ }^{101}$ Meir Bar-Ilan, Some Jewish Women in Antiquity (Atlanta: Scholars Press, 1998), 73-6.

${ }^{102}$ The battle over the public lamenting of women started in Greece, continued in Rome, and was a big issue for the church fathers. Chrysostom was outraged that people were using them instead of clergy in funerals (Hom. In John 62:4), and moreover, pagan women. A synod in Syria in 576 banned girls from learning music and mourning practices. In short - women's public mourning was conceptualized as giving them too much power. See: Sharon Lorraine Murphy Mogen, "Women and Death Rituals in Late Antiquity: Forming the Christian Identity" (MA Thesis, University of Calgary, 2011), 117-18.

${ }^{1093}$ Baskin, Midrashic Women, 69.

${ }^{104}$ Corbiell, Nature Embodied, 80. He refers to Roman funerals but as I learn more about funerals in late antiquity it looks more and more as though the processions looked quite identical, regardless of religion. 
appears in this unit. Alas, it is hardly the best one the Bible has to offer. In the verse quoted from Job, it is a man who draws other men after him to the grave, not a woman. The joke, so it seems, is on us.

9. And why is the precept of Niddah given to her? Because she spilled the blood of the first man, that's why she is given it.

10. And why is the precept of Hallah given to her?

He told them: because she ruined the first man who was the Hallah of the world, that's why it was given to her.

11. And why was the precept of lighting the Shabbat candle given to her?

He told them because she put out the [light of the] soul of the first man, that is why it was given to her.

In the final three questions the logic is made very clear, which makes all women carry the burden of Eve's sin. It is either the carnival's peak, the uncrowning of the king, or the most misogynist point of the text.

A tradition that binds together ner, niddah, and hallah, the three 'feminine precepts', ${ }^{105}$ to sin appears already in Mishnah Shabbat 2:6 that states: 'Women die in childbirth as a consequence of three sins: because they are not observant of niddah, hallah, and the kindling of the [Sabbath] lights.' Eve is nowhere to be found and the 'sins' are not ones of which she was guilty.

Seven rabbinic interpretations of the Mishnah exist: in two of them (Kohelet Rabbah 3:3, BT Shabbat 31b-32a) Eve is not mentioned. In another three (ADRN B 9, Tanhuma Noah a; Tanhuma Mezora 9), these commandments are given to women to atone for Eve's sin, but they have no part in her sin. Only in our text and in the anonymous YT Shabbat (2:6) 20a is all womankind to blame for Eve's sins. In the Yerushalmi, however, the context is judgment at childbirth for not following the three precepts, not an inherent female guilt. ${ }^{106}$ In short, only once, here, does anyone dare to suggest that there are commandments which are indeed not an expression of God's covenant with His people, but punishments and curses. This, I believe is nothing less than a theological bomb, a monstrous and grotesque depiction of the relationship between God, Israel, and Torah. I do not know of any other rabbinic source that claims that any commandment was given to Israel as a punishment, and the idea itself is absurd, as both ADRN B, Kohelet Rabbah and the Bavli notice, when they reject this concept, implicitly or explicitly, as Boyarin has demonstrated. ${ }^{107}$

The grotesque, and the inverted logic here is so monstrous that it falls into the realm of the serio-comic. I fail to see in it anything other than an ironic stance of R. Yehoshua, or rather of the editor of Genesis Rabbah. Placing this segment at the end of the parashah, and shaping it in the form of a sequence of questions and answers - a form in which it does not appear anywhere else, not even in the Yerushalmi - might suggest we are actually facing a satirical use rather than a naive one of the womensin-ner/niddah/hallah theme. The quadruple chant 'because of Eve', which has nothing to do with creation from the rib anymore is plain evil, or darn funny, and I refer you again to Aeschylus's little oil flask.

The list of eleven questions that were asked of Rabbi Yehoshua is quite clearly not a description of an actual event. It has no full parallel in rabbinic literature, and its closest variant is a list of eight questions found in ADRN B, 9, which does not mention R. Yehoshua. The list there is followed by a discussion of sins for which women die at childbirth. Kister brings ADRN B, 8-9 as an example of the complicated relationship between Genesis Rabbah and ADRN. Since he cannot conclude that

\footnotetext{
${ }^{105}$ Both Kraemer and Baskin argue that there is no evidence that women actually practiced ner, niddah and hallah the way the rabbis wanted them to, which might account for the discursive violence which is manifested around them, they also remind us that men are also obliged by the same precepts. See Ross Shepard Kraemer, Her Share of the Blessings: Women's Religions among Pagans, Jews, and Christians in the Greco-Roman World (New York and Oxford: Oxford University Press, 1993), 99-101; Baskin, Midrashic Women, 71-3.

${ }^{106}$ In the Yerushalmi the unit appears also in the context of child-bearing and times of danger, suggesting that our midrash is one of a kind.

${ }^{107}$ Daniel Bovarin, Carnal Israel, 92-4. More on the three 'feminine' precepts: Leila Leah Bronner, From Eve to Esther: Rabbinic Reconstructions of Biblical Women (Louisville: Westminster/John Knox, 1994), 30-1.
} 
ADRN copied Genesis Rabbah, as it takes Genesis 2:23 and not 2:21 as its point of departure, he assumes that it copied a third text, resembling Genesis Rabbah but not identical to it, now lost. ${ }^{108}$ True or not, it is clear that Genesis Rabbah takes a very different approach to the shared tradition. As we have seen, whenever ADRN could, it chose a more 'rational' and acceptable version of the 'fake facts' and their explanation, taking the sting out of the absurd, and creating, in fact, a rather misogynist text. It chooses l'hitpayes over l'hitpatot, switches perfume as a necessity for a habit of adornment, turns the new-born female facing up to a grown woman looking at a man, ${ }^{109}$ and finally presents the commandments for women as means of atonement, not punishment, and as a part of a different sequence. The radicalization and the technique of reductio ad absurdum of Genesis Rabbah become clearer now.

I began this article by arguing that an editor's hand can easily be felt in this parashah. Most of what we read is attested in one version or another in the sea of rabbinic literature, but it is the careful craft of the editor that shows the funny face of what might be horrifyingly grotesque moments and comments, and doubts the undoubtable: that rabbis cannot laugh at the ideology that they themselves inscribe. The suspicion that this text may not be the epitome of misogyny, which arose as the parashah started with the inclusion women in the creation by logoi, continued with the doubling effects, mimicking the double creation story, which peaked in the choice to bring traditions on the names of three pairs of rabbis carrying identical names, and the final pair of Rabbi Rib and Rabbi Mummy gave the suspicion more depth. The fake facts logic, and the ever more creative and sometimes contradictory explanation of those, as well as the obsession with the lower parts of the body points again in the same direction. Add to this the choice of Rabbi Yehoshua, the piling up of eleven questions which is never repeated in rabbinic literature, and the use of only one (inadequate) biblical verse but always of parables. To top, sprinkle the absurdity of presenting commandments as divine punishments, and you get one of the most satiric, reflective, and perhaps funny texts in rabbinic literature. It is, if you will, the carnival of misogyny. The carnival makes its final appearance here, as its power structure, as well as its use of the body is relevant to our parashah. This parashah is unusual, I suggest, not for its misogyny, but rather for its choice not to surrender to it, at least not without a fight. Its deep engagement with the creation of the human body and its aftermath may serve not only to interpret the Bible, but much like the carnival, to fortify the identity of the (Jewish) collective through laughter and through the changing collective body: that which was created of the earth and since then gives birth, copulates, conceives, eats, defecates, dies, and is born. The carnivalesque humour embodies a profound honour of and respect for this body. This is a humour that acknowledges the powerful divine mysteries as well as the transcendence of the human spirit through an ongoing creation of the body, through and by all of its openings. But just like the carnival, and in the case of many serio-comic texts, this euphoric state is short lived. The carnival ends, and the old ways prevail. The ridiculed king still reigns and history remembers that the fool was mocked, not that he is a reflection of the king. And so, in the case of our parashah, what was once a live, playful, hopeful text is violently ripped to pieces, by ancient and by moderns, and lives on to serve the same ideology it subverts. Let us change that.

\footnotetext{
${ }^{10}$ Menahem Kister, Studies in Avot de-Rabbi Natan: Text, Reduction and Interpretation (Jerusalem: Yad Izhak Ben Zvi, 1998), 205-206.

${ }^{109}$ A parallel to this can be found in a piece of Hagiography about Ephraim of Syria: "When Ephraim went into Edessa for the first time, he prayed that as he entered the town he would meet someone who would discuss with him the problem in Holy Scripture. The first person he met, coming straight towards him, was a woman who was a prostitute. Ephraim was sad because he thought God had not heard his prayers, for what did she know of the Bible? How could she help resolve his questions? But the woman came on, her eves fixed upon him. He was astonished and said to her, but without impatience or anger, "why are you looking at me so intensely?" The woman replied with a reference to the story in Genesis of the creation of man and woman, "It is natural that I should look at you, for I was formed out of you; but as for you, you have no reason to look at me for it was the earth from which you were formed and it is on that that your eyes should be fixed.” Vita St. Ephraem, PL 73, col. 2321-22, Harlots of the Desert, trans. Benedicta Ward (Kalamazoo: Cistercian, 1987), 61.
} 


\section{BIBLIOGRAPHY}

Alexander, Philip. "Pre-Emptive Exegesis: Genesis Rabba's Reading of the Story of Creation." Journal of Jewish Studies 43/3 (1992): 230-45.

Artman, Tali. Dialog, Mitos ve-Yitzug Demui Historia: Keria be-Shiv'a Mifgashim Bein Matrona le-R. Yossi be-Bereishit Rabba. MA Research Paper, Hebrew University, Jerusalem, 2002.

Bakhtin, Mikhail. Problems of Dostoevsky's Poetics, trans. Caryl Emerson. Minneapolis and London: University of Minnesota Press, 1984.

Bakhtin, Mikhail. Rabelais and his World, trans. Helene Iswolsky. Bloomington: Indiana University Press, 1984.

Bar-Ilan, Meir. Some Jewish Women in Antiquity. Atlanta: Scholars Press, 1998.

Barthes, Roland. "The Death of the Author," in William Irwine, ed., The Death and Resurrection of the Author. ' Contributions in Philosophy 83. Westport, Conn.: Greenwood Press, 2002.

Baskin, Judith. Midrashic Women: Formations of the Feminine in Rabbinic Literature. Hanover; London: University of New England for Brandeis University Press, 2002.

Beard, Mary. Laughter in Ancient Rome: On Joking, Tickling, and Cracking $U p$. Berkeley: University of California Press, 2014.

Bloch, R. Howard. Misogyny, Misandry and Misanthropy. Berkeley: University of California Press, 1989.

Boyarin, Daniel. Carnal Israel: Reading Sex in Talmudic Culture. Berkeley; Oxford: University of California Press, 1995.

Boyarin, Daniel. Socrates and the Fat Rabbis. Chicago: University of Chicago Press, 2009.

Brenner, Athalya, ed. Are We Amused? Humour about Women in the Biblical Worlds. London; New York: T \& T Clark/Continuum, 2003.

Bronner, Leila Leah. From Eve to Esther: Rabbinic Reconstructions of Biblical Women. Louisville: Westminster/John Knox, 1994.

Brown, Peter. The Body and Society. New York: Columbia University Press, 1988.

Burrus, Virginia. "Carnal Excess: Flesh at the Limits of Imagination.” Journal of Early Christian Studies 17/2 (2009): 247-65.

Cantarella, Eva. Pandora's Daughters: The Role and Status of Women in Greek and Roman Antiquity, trans. Maureen B. Fant. Baltimore: Johns Hopkins University Press, 1987.

Carson, Anne. "The Gender of Sound." Thamyris 1: 10-31, 1994: 10-31.

Clark, Elizabeth A. "Dissuading from Marriage: Jerome and the Asceticization of Satire," in Warren S. Smith, ed., Satiric Advice on Women and Marriage: From Plautus to Chaucer. Ann Arbour: University of Michigan Press, 2005.

Classen, Constance, David Howes, and Anthony Synott. Aroma: The Cultural History of Smell. London and New York: Routledge, 1994.

Corbeill, Anthony. Nature Embodied, Gestures in Ancient Rome. Princeton: Princeton University Press, 2004.

D’Angelo, Mary Rose. "Veils, Virgins and the Tongues of Men," in Howard Eilberg-Schwartz and Wendy Doniger, eds., Off with Her Head! The Denial of Women's Identity in Myth, Religion, and Culture, 131-65. Berkeley: University of California Press, 1995.

Derrida, Jacques. Of Grammatology, trans. Gayatri Chakravorty Spivak. Baltimore; London: Johns Hopkins University Press, 1997.

Dio, Cassius. Roman History: with an English Translation by Earnest Cary and Herbert B. Foster. Cambridge: Harvard University Press, 1914.

Drake, Susanna. Slandering the Jew: Sexuality and Difference in Early Christian Texts. Philadelphia: University of Pennsylvania Press, 2013. 
Fewell, Danna Nolan. "Reading the Bible Ideologically: Feminist Criticism," in Steven L. McKenzie and Stephen R. Haynes, eds., To Each Its Own Meaning: An Introduction to Biblical Criticisms and Their Application, 268-82. Louisville: John Knox Press, 1999.

Flemming, Rebecca. Medicine and the Making of Roman Women: Gender, Nature and Authority from Celsus to Galen. Oxford: Oxford University Press, 2000.

Fonrobert, Charlotte. "Regulating the Human Body: Rabbinic Legal Discourse and the Making of Jewish Gender," in Charlotte Fonrobert and Martin Jaffee, eds., The Cambridge Companion to the Talmud and Rabbinic Literature, 270-73. Cambridge: Cambridge University Press, 2007.

Goldhill, Simon. Who Needs Greek? Contests in Cultural History of Hellenism. New York: Cambridge University Press, 2002.

Goldhill, Simon. “Good, Dirty Fun.” Times Literary Supplement August 31, 2016.

Greenspoon, Leonard J. Jews and Humor. West Lafayette, Indiana: Purdue University Press, 2011.

Griswold, Charles L. "Irony in the Platonic Dialogues." Philosophy and Literature 26 (2002): 84-106.

Gruen, Erich S. Heritage and Hellenism: The Rejuvenation of Jewish Tradition. Berkeley; London: University of California Press, 1998.

Halevi, E. E. Olamah shel ha-agadah: Ha-agadah le-or mekorot Yevaniyim. Tel Aviv: Dvir, 1972.

Harvey, Susan Ashbrook. "Women in the Early Syrian Christianity," in Averil Cameron and Amélie Kuhrt, eds., Images of Women in Antiquity. London: Croom Helm, 1983.

Harvey, Susan Ashbrook. Scenting Salvation: Ancient Christianity and Olfactory Imagination. Berkeley: University of California Press, 2006.

Hasan-Rokem, Galit. Web of Life: Folklore and Midrash in Rabbinic Literature. Stanford: Stanford University Press, 2000.

Hasan-Rokem, Galit. "Did Rabbinic Culture Conceive of the Category of Folk Narrative?" European Journal of Jewish Studies 3/1 (2009): 19-55.

Hasan-Rokem, Galit. "Conception, Pregnancy and Birth in the Rabbinic Imagination of Leviticus Rabbah 14: Preliminary Remarks," in Israel Bartal, Galit Hasan-Rokem, Ada RapoportAlbert, Claudia Rosenzweig, Vicky Shifris and Erika Timm, eds., A Touch of Grace: Presented to Chava Tumiansky, 393-422 [Hebrew]. Jerusalem: The Zalman Shazar Center, 2013.

Heinemann, Joseph. "Profile of a Midrash: the Art of Composition in Leviticus Rabba." Journal of the American Academy of Religion 39 (1971): 141-50.

Heinemann, Joseph. "The Structure and Division of Genesis Rabba," in H. Z. Hirschberg et al., eds., Jubilee Volume for Hayyim Moshe Shapira (Ramat Gan: Bar-Ilan University Press, 1972) 279-89 [Hebrew].

Hyers, Conrad. And God Created Laughter: The Bible as Divine Comedy. Atlanta: Westminster John Knox Press, 1987.

Ilan, Tal. Integrating Women into Second Temple History. Tübingen: Mohr Sieback, 1999.

Ilan, Tal. "The Joke in Rabbinic Literature: Home-born or Diaspora Humor?" in G. Tamer, ed., Humor in Arabic Culture, 57-75. Berlin: De Gruyter 2009.

Jackson, Melissa A. Comedy and Feminist Interpretation of the Hebrew Bible: A Subversive Collaboration. Oxford: Oxford University Press, 2012.

Jastrow, Marcus. Dictionary of the Targumim, the Talmud Babli and Yerushalmi, and the Midrashic literature. Peabody, Mass.: Hendrickson Publishers, 2005.

Jónsson, Jakob. Humour and Irony in the New Testament: Illuminated by Parallels in Talmud and Midrash, with a Foreword by Krister Stendahl, and an Epilogue. Leiden: Brill, 1985.

Kaniel, Ruth Kara-Ivanov. "Seed That Comes From Another Place: The Metamorphosis of the Story of Lot's Daughters." Jerusalem Studies in Jewish Thought 22 (2011): 91-119.

Kahana, Menachem. "Shes mishzar: Le'Sidura shel parashat 'Bereshit Bara' be'midrash Bereshit Rabbah,” in Joshua Levinson, Jacob Elbaum, Galit Hasan-Rokem, eds., Higayon L'Yona: 
New Aspects in the Study of Midrash, Aggadah and Piyyut In Honor of Professor Yona Fraenkel, 357-376. Jerusalem: Magnes, 2007.

Kasher, Menachem Mendel. Humash Torah shelemah: ve-hu ha-Torah shebi-khetav'im be'ur "Torah shebe-'al peh.” Jerusalem: Noam Aharon, 1994 [Hebrew].

Kiperwasser, Reuven. Review of Daniel Boyarin, Socrates and the Fat Rabbis. Jewish History 25/3-4 (2011): 382.

Kister, Menahem. Studies in Avot de-Rabbi Natan: Text, Reduction and Interpretation. Jerusalem: Yad Izhak Ben Zvi, 1998.

Kovelman, Arkadi. "Farce in the Talmud." Review of Rabbinical Judaism 5/1 (2002): 86-92.

Kraemer, Ross Shepard. Her Share of the Blessings: Women's Religions among Pagans, Jews, and Christians in the Greco-Roman World. New York and Oxford: Oxford University Press, 1993.

Kushelevsky, Rella. "The Function of Humor in Three Versions of the Theme Rabbi Joshua Ben Levi and the Angel of Death." Jerusalem Studies inJewish Folklore 19-20 (1998): 329-44 [Hebrew].

Levine, Molly. "The Gendered Grammar of Ancient Mediterranean Hair," in Howard EilbergSchwartz and Wendy Doniger, eds., Off with Her Head! The Denial of Women's Identity in Myth, Religion, and Culture, 76-130. Berkeley: University of California Press, 1995.

Levinson, Joshua. "Upside Down World: The Story of the Drunk and His Sons." Jerusalem Studies in Hebrew Literature 14 (1993): 7-29 [Hebrew].

Levinson, Joshua. “An-Other woman: Joseph and Potiphar's wife - Staging Body Politics.” Jewish Quarterly Review 87/3-4 (1997): 269-301.

Levinson, Joshua. The Twice-Told Tale: A Poetics of the Exegetical Narrative in Rabbinic Midrash. Jerusalem: Magnes Press, 2005 [Hebrew].

Levison, John. "Is Eve to Blame? A Contextual Analysis of Sirach 25:24." Catholic Biblical Quarterly 47/4 (1985): 617-23.

Meir, Ofra. The Exegetical Story in Genesis Rabbah. Tel Aviv: Hakibbutz Hameuchad, 1987 [Hebrew].

Meir, Ofra. "A Garden in Eden: On the Redaction of "Genesis Rabba." Dappim: Research in Literature 6/5 (1989): 309-30 [Hebrew].

Meir, Ofra. "Ma'ase ha'arikha bebereshit rabba ub'vayikra rabba.” Teuda 11 (1996): 61-90.

Meir, Ofra. "Ekron ha'haluka leparashot b'bereshit Rabba." Proceedings of the Tenth World Congress of Jewish Studies 3/1 (2000): 101-8;

Milikowsky, Chaim. "On the Formation and Transmission of Bereshit Rabba and the Yerushalmi: Questions of Redaction, Text-Criticism and Literary Relationships." The Jewish Quarterly Review 92/3-4 (2002): 521-67.

Mogen, Sharon Lorraine Murphy. "Women and Death Rituals in Late Antiquity: Forming the Christian Identity." MA Thesis, University of Calgary, 2011.

Padgett, Alan. "Paul On Women in the Church: The Contradictions of Coiffure in 1 Corinthians 11.216." Journal for the Study of the New Testament [JSNT] 20 (1984): 69-86.

Pardes, Ilana. Countertraditions in the Bible. Cambridge, Mass. and London: Harvard University Press, 1993.

Prusak, Bernard P. "Women: Seductive Sirens and Source of Sin? Pseudoepigraphical Myth and Christian Origins," in Rosemary Radford Ruether, ed., Religion and Sexism: Images of Woman in the Jewish and Christian Traditions. New York: Simon and Schuster, 1974.

Reines, Chaim W. "Laughter in Biblical and Rabbinic Literature.” Judaism 21 (1972): 176-83.

Rosen-Zvi, Ishay. "Misogyny and its discontent." Review of Judith Baskin, Midrashic Women: Formations of the Feminine in Rabbinic Literature. Prooftexts 20 (2005): 221.

Rosen-Zvi, Ishay. "Do Women Have a Yetzer? Anthropology, Ethics and Gender in Rabbinic Literature," in H. Kreisel, B. Huss, and U. Ehrlich, eds., Spiritual Authority: Struggles over Cultural Power in Jewish Thought, 21-34. Be'er Sheva: Ben Gurion University Press, 2010 [Hebrew]. 
Rosen-Zvi, Ishay. "The Rise and Fall of Rabbinic Masculinity." Jewish Studies, an Internet Journal [JSID] 12 (2013): $1-22$

Rouselle, Aline. Proneia, trans. Felicia Pheasant. Oxford and New York: Blackwell, 1998.

Salmon, Rachel, and Gerda Elata-Alster. "Retracting a Writerly Text: In the Footsteps of a Midrashic Sequence on the Creation of Male and Female," in Ann Loads and Michael McLain, eds., Hermeneutics, the Bible and Literary Criticism. London: Macmillan, 1992.

Satlow, Michael L. Jewish Marriage in Antiquity. Princeton: Princeton University Press, 2001.

Satlow, Michael. "Male or Female Did They Create It? Gender and the Judaism of the Sage," in Lee. I. Levine, ed., Continuity and Renewal:Jews andJudaism in Byzantine-Christian Palestine, 486504. Jerusalem: Yad Ben-Zvi Press, 2004 [Hebrew].

Sperber, Daniel. Material Culture in Eretz Israel During the Talmudic Perod, vol. 2. Jerusalem: Yad Izhak Ben Zvi Press, 2005 [Hebrew].

Stein, Dina. "Let the "People" Go?" Prooftexts 29/2 (2009): 206-41.

Thompson, Cynthia. "Hairstyles, Head Covering and St. Paul: Portraits from Roman Corinth." Biblical Archaeologist 51 (1988): 99-115.

Travis, L. Ann. "But I Want You to Know...: Paul's Midrashic Intertextual Response to the Corinthian Worshipers (1 Cor 11:2-16).” Journal of Biblical Literature 112 (1992): 231-46.

Trible, Phyllis. God and the Rhetoric of Sexuality. London: SCM, 1978.

Waisanen, Don, Hershey Friedman, and Linda Friedman, "What's So Funny about Arguing with God? A Case for Playful Argumentation from Jewish Literature.” Argumentation 29/1 (2015): 5780 .

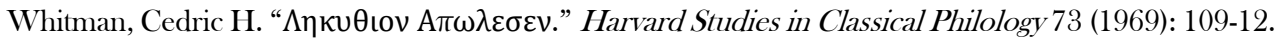

Walker, William. "1 Corinthians 11:2-16 and Paul's view Concerning Women." Journal of Biblical Literature 94 (1975): 94-100.

Ward, Benedicta. Harlots of the Desert. Kalamazoo: Cistercian, 1987.

Wyke, Maria. "Woman in the Mirror: The Rhetoric of Adornment in the Roman World," in Léonie J. Archer, Susan Fischler, and Maria Wyke, eds., Women in Ancient Societies: An Illusion of the Night. Basingstoke: Macmillan, 1994.

Zellentin, Holger Michael. Rabbinic Parodies of Jewish and Christian Literature. Tübingen: Mohr Siebeck, 2011. 